\title{
RECOGNIZING AND IMPLEMENTING INTERNATIONAL HUMAN RIGHTS STANDARDS IN DOMESTIC LEGISLATION: AN EXPOSURE UNDER UKRAINIAN LAW
} RECONOCIMIENTO Y APLICACIÓN DE LOS ESTÁNDARES INTERNACIONALES DE DERECHOS HUMANOS EN LA LEGISLACIÓN NACIONAL: UNA EXPOSICIÓN BAJO LA LEY UCRANIANA

Vitalii Oleksandrovych Serohin*

Svitlana Hryhorivna Serohina**

Liliya Mykolayivna Gryshko ${ }^{* * *}$

Kateryna Petrivna Danicheva****

\begin{abstract}
Everything about human right is inalienable void of violation from the human race. It is therefore that responsibility of the international community in ensuring the effective preservation and respect of these rights without any threat of violations. In ensuring its recognition and implementation, international standards have been established where there is the need of States parties to these international human right treaties in ensuring its incorporation in its various domestic legislations. The content and specific features of the introduction of international human rights standards into national legislation have been analyzed in the article. The

\footnotetext{
* Doctor of Legal Sciences. Professor. Professor of the Constitutional and Municipal Law Department of the School of Law of the V. N. Karazin Kharkiv National University. https://orcid.org/0000-0002-1973-9310. v.a.seryogin@karazin.ua

** Doctor of Legal Sciences. Professor. Head of the State Building Department of the Yaroslav Mudryi National Law University. https://orcid.org/0000-0002-0107-834X. ndi_db_ms@ukr.net

*** Candidate of Legal Sciences. Senior Researcher at the Scientific Research Institute of State Building and Local Self-Government of the National Academy of Legal Sciences of Ukraine. https://orcid.org/0000-0003-0347-1118. gryshko.lm@gmail.com

**** Candidate of Legal Sciences. Associate Professor of the Constitutional and Municipal Law Department of the School of Law of the V. N. Karazin Kharkiv National University. https://orcid.org/0000-0003-0034-8499. ekaterinadanicheva@gmail.com
} 
methodological basis of research is a set of general scientific and special methods, in particular, dialectical, historical-legal, epistemological, comparative-legal. International standards for the protection of human rights have been defined as principles and norms enshrined in international regulatory legal acts that define fundamental human rights and freedoms, the obligation of the State to respect them, to assist in their realization, preservation and protection against unlawful encroachments, and to establish liability for their violations and methods of protection. It has been clarified that the procedure of implementation of international human rights standards into national legislation includes the following stages: (i) recognition of human rights by the State and their enshrinement in national legislation; (ii) institutionalization of the standard of human rights protection; (iii) bringing the current legislation in line with the international human rights standard and interpreting the latter; (iv) establishment of measures and means of protection and defense of human rights; (v) determining the procedure for the realization of the enshrined right; (vi) control over the observance of the international human rights standard.

Keywords: Human Rights, International Standards, Rights Protection, Implementation

Resumen: Los derechos humanos son inalienables, de modo que no debe darse violación alguna por parte de las personas. Por lo tanto, es responsabilidad de la comunidad internacional garantizar la preservación y el respeto efectivo de estos derechos sin ninguna amenaza. Para asegurar su reconocimiento e implementación, se han establecido estándares internacionales al momento que exista la necesidad de que los Estados partes en los tratados internacionales de derechos humanos aseguren su incorporación en sus diversas legislaciones nacionales. En el presente artículo se analizan el contenido y las características específicas de la introducción de las normas internacionales de derechos humanos en la legislación nacional ucraniana. La base metodológica de la investigación se cimienta en un conjunto de métodos científicos generales y especiales, tales como el dialéctico, el histórico-legal, el epistemológico y el comparado-legal. Los estándares internacionales para la protección de los derechos humanos se han definido como principios y normas consagrados en actos jurídicos regulatorios internacionales que definen los derechos humanos y las libertades fundamentales, la obligación del Estado de respetarlos y ayudar a su realización, preservación y protección contra las vulneraciones ilícitas, así como establecer responsabilidad por sus violaciones y métodos de protección. Mediante esta investigación, se aclara 
que el procedimiento de implementación de las normas internacionales de derechos humanos en la legislación ucraniana comprende las siguientes etapas: (i) reconocimiento de los derechos humanos por parte del Estado y su consagración en la legislación nacional; (ii) institucionalización del estándar de protección de los derechos humanos; (iii) adecuación de la legislación vigente al estándar internacional de derechos humanos $e$ interpretación; (iv) establecimiento de medidas y medios de protección y defensa de los derechos humanos; $(v)$ determinación del procedimiento para la realización del derecho consagrado; y (vi) control de la observancia de la norma internacional de derechos humanos.

Palabras clave: Derechos humanos, estándares internacionales, protección de derechos, implementación

Summary. I. Introduction. II. Methodology. III. Literature Review. IV. Results and Discussion. V. Questioning the Available Procedure in Recognizing the Need of Protecting Human Rights Standards. VI. Conclusion. References.

\section{INTRODUCTION}

Nowadays, towards becoming a democratic society in Ukraine, priority is given to developing legal guarantees for the protection of human rights and freedoms (Ablamskyi, et al., 2020a). The problem of effective provision of the protection of the aggrieved person's rights has always existed, and even despite the ratification by Ukraine of a number of international documents that guarantee every person fundamental rights and freedoms. Under these conditions, the key issue should be the development and introduction of an effective legal mechanism for protecting the rights of the person on the one hand and their updating on the other. This will be evidence that the state as a whole and its law enforcement bodies are ready to fulfill their international obligations (Ablamskyi, et al., 2020b). Ukraine's integration into the European Community and the rapid development of international relations require the states to review the mechanism of human rights protection as their main duty. The problem of affirmation and protection of human rights has gone far beyond one state and requires the development and implementation of common universal standards both directly for human rights and mechanisms for their protection. This issue is currently regulated by a number of international regulatory legal acts that define fundamental human rights, which cannot be limited or unrecognized by Member States. Each country should focus its activities on the 
observance of the indicated rights in all available ways. At the same time, the legislative consolidation of both human rights standards and mechanisms for their implementation acquires special significance.

The purpose of the article is to reveal the content of international legal standards for the protection of human rights and their implementation into national law. To achieve this purpose, it is necessary to solve the following objectives: (i) To characterize the content of the categories of standard, human rights and human rights standard; (ii) To determine the system of regulatory legal acts that establish human rights standards; (iii) To analyze national legislation in order to enshrine international human rights standards; (iv) To clarify the procedure for implementing international human rights standards into national legislation.

\section{METHODOLOGY}

In accordance with the purpose of the article, the methodological basis of the study was chosen. The general and special scientific methods and techniques of scientific cognition constitute the methodological basis of the paper. The dialectical method was the methodological basis of research and was used, in particular, in the analysis of basic theoretical data related to modern international standards of protecting human rights, to reveal their essential content. The historical-legal method allowed us to outline the formation and development of understanding of international human rights standards. The epistemological method was used to clarify the content of the category's standard, human rights and human rights standard. The use of the comparative-legal method is the basis for the analysis of the state of implementation of international human rights standards into national legislation. Truly, putting in place a comparative research methodology is imperative for the recognition of the human right standard, but ensuring that States like that of Ukraine incorporate them into their domestic legislation has always been a great plague and problem. Sometimes it is not only incorporating the human rights provisions into domestic laws that are of prime concerned, but rather at the level of implementation that becomes the real difficulty. Most of the time we always experienced violations of the said human right standard set by the national disposition. The question one need to pose here is in questioning for how long human right standard will be guarantee and implemented in Ukraine when we keep on experiencing constant violations. This is a really a complete hallucinations as far as human right protection is recognized in Ukraine. 


\section{LITERATURE REVIEW}

Human rights issues have always attracted considerable attention among scholars, politicians and lawmakers. This issue is also relevant for Ukraine and, moreover is gaining importance in regard to the European integration course, so the study on the introduction of international human rights standards into national law is widely used in scientific sources. As noted by P. Rabinovych (2013), the problem of fundamental ("natural") human rights, the regularity of their implementation, development, protection and defense is now the core of the subject matter of general theoretical jurisprudence. And one of the fundamental aspects of this problem is the matter of the social essence of such rights.

M. Orzikh (1992) has once studied international legal standards and human rights in Ukraine. The scholar has already stressed at that time that the initiated course of state policy required appropriate actions, primarily from government agencies in regard to rethinking the content and functional focus of their activities.

O. V. Kyivets (2012) studied European legal standards as an international legal category. The author came to the conclusion that the whole system of the standards regulating various aspects of international relations has been created and de facto successfully functions in the international law. Some of them belong to the priority areas of public relations regulation. European legal standards acquire special significance for further improvement of the legal system of Ukraine and its entry into the European legal space. This requires an active study of the main areas of legal regulation, especially in the activities of the European Union and the Council of Europe to implement and comply with European standards regulating the most important areas of public relations.

H. H. Shmelova (2014) studied international regulatory legal and international organizational and legal guarantees of human rights and freedoms. The scholar has noted that human rights and freedoms are one of the key scientific problems that are comprehensively studied-from a philosophical and humanistic point of view, in terms of the principles of restructuring the legal system, conducting economic and cultural policy. The inexhaustibility of human rights and freedoms is a reflection of the nature of their bearer - a human being, and therefore they should be analyzed holistically, comprehensively, as a category of multifaceted and multifunctional. The universal nature of human rights and freedoms determines the fact that they are the subject of the research of all branches of social sciences and a number of legal sciences, where each of them 
determines a particular area of human life. Legal science in the field of human rights and freedoms has its own complex range of research.

P. Rabinovych and O. Venetska (2012) have characterized the main features of international human rights standards that are reflected in this definition of these standards. Scholars have also outlined a classification of such standards.

T. M. Slinko (2018) has studied international and legal standards in the field of human rights and their reflection in the Constitution of Ukraine. The author has noted that the protection and observance of fundamental human and civil rights and freedoms in the modern world have ceased to be the competence of a particular country but have become a matter for the entire international community, since it has long been a more important task of many countries of the world community. Due to the increased concern and attention of the international community to these issues at various times, authoritative international organizations have adopted about 300 declarations, conventions, charters. International and legal acts in the field of human rights generally consider international standards, since they are developed on the basis of customary norms formed by the States' recognition of the legal force of conduct norms promulgated by the United Nations General Assembly in the form of declarations or recommendations.

L. R. Nalyvaiko and K. V. Stepanenko (2019) studied the main theoretical provisions and practice for the creation and implementation of international legal standards of human rights. The authors also studied the legal content of international and legal human rights standards, defined the mechanism for the formation and provision of international human rights standards, highlighted issues related to the compliance with international human rights standards in the activities of judicial, law enforcement and human rights agencies of Ukraine.

Ablamskyi, Hlobenko, Chycha, Martovytska and Burlaka (2020) analyzed of international law acts, which guarantee the protection of the rights of aggrieved persons in criminal proceedings. It is emphasized that, in recent decades, the international community has adopted a number of important international legal documents in the field of protecting human rights and freedoms. The norms of both universally recognized documents and documents of the regional level, that is, those developed by the Council of Europe and set forth in the relevant Recommendations have been cited and analyzed.

Viktor, Herasymchuk, Zuieva, Tuieva and Kartsyhin (2021) conducted a comprehensive analysis of the problem of protecting property rights against a terrorist threat and finding ways to solve it. The authors considered the main problems of protection of property rights under 
conditions of external military aggression in Ukraine. The example of separate case analyses the problematic aspects of renewing and granting property rights to citizens residing in the temporarily occupied territory of Ukraine.

\section{RESULTS AND DISCUSSION}

With the philosophical notion of human rights, from the classical conception of natural law, through the Hellenic world with Antigone, Christian philosophy, the description of despotism illustrated in the century of Enlightenment, the formal description of Western declarations of independence and rights of man and of the citizen, it is possible to recognize the paradigm of a single international recognition of human rights (Garzón Buenaventura, 2016).

The problem of protecting rights is rather topical for the modern Ukrainian state. Since the beginning of the conflict in the east of Ukraine and the annexation of the Crimean Peninsula, several years have passed, however, the state has not succeeded in building effective protection policies for the affected victims (Herasymchuk, et al., 2021). One of the basic concepts that underlies law as a phenomenon, as well as private law as one of the two areas of law, is the concept of natural law. This concept presupposes those rights and freedoms are an inalienable good of every person, regardless of the will of any external institutions. The ideas of natural law have been expressed in the concept of private law-the fundamental principles of private law are such principles as justice, good faith, reasonableness, dispositiveness, legal certainty, inadmissibility of interference in private affairs, inviolability of property rights, and freedom of contract (Tkalych, Safonchyk \& Tolmachevska, 2020).

Anti-epidemic measures introduced in Ukraine to prevent the spread of COVID-19 include significant (though often implicit) restrictions on the implementation of economic, social and cultural human rights, where the issues of reasonableness and legitimacy require particular attention, when the state of emergency in Ukraine is not announced. The lawful introduction of a number of reasonable and proportional restrictions on the implementation of economic, social and cultural human rights within the framework of preventive and anti-epidemic measures to prevent the spread of COVID-19 in Ukraine is justified in general by the interests of effective protection against this infectious disease. Some of the significant restrictions on the implementation of these human rights in connection with the COVID19 pandemic in Ukraine are unsystematic and have contradictory legal 
nature, are insufficiently justified and proportionate to anti-epidemic goals, demonstrate the features of discrimination, are insufficiently specified in content and implementation procedure, as well as are not provided with additional guarantees for the realization of these human rights (Zozulia, 2020). The above fact additionally testifies to the need to study international standards for the protection of human rights, since every year the Ukrainian district takes more and more efforts to improve national legislation and its adaptation to international standards and principles.

The formal clarity of law implies a set of precise, unambiguous and transparent legal requirements for both lawmaking and law-enforcement processes designed to ensure the realization of human rights, interests and freedoms, as well as protection against possible manifestations of state arbitrariness that makes it possible to avoid a number of mistakes, offenses and misunderstandings of life situations (Silantieva, 2021). Specific features of introducing international human rights standards into national legislation should start with defining the content and types of such standards. The explanatory dictionary of the Ukrainian language defines that the standard is the features of a certain phenomenon established by the competent authority, custom or by common consent as a model or a pattern (Busel, 2009, p. 1383). It is a guideline, a model that should be used because of its reasonableness and practical value, and which assists in the harmonization of the norms of national legal systems in socially important areas (Kyivets, 2012 , p. 74). Thus, the standard is a certain pattern that serves to harmonize certain phenomena or processes. Standards in legal practice are designed to ensure the unity of legal norms both within the state and in the world.

Human rights are a person's social ability to act freely, independently choose the type and measure of own behavior in order to meet own diverse financial and spiritual needs by using certain social benefits within the limits set by law (Rabinovych, 2010, p. 12). It is the limit of permissible human behavior, which is implemented in order to meet certain needs and interests.

International regulatory legal acts and the Constitution of Ukraine have proclaimed human rights as the highest social value and obliged states to protect them and preserve them from illegal restrictions and unlawful encroachments. To this end, international organizations issue conventions and other acts that constitute the system of universal international law norms in order to establish standards in the field of human rights and freedoms and which are binding for all states. These guarantees include international legal acts on human rights and international legal procedures, within which the activities of certain international institutions in the field of human rights are carried out (Shmelova, 2014, pp. 100-101). 
International and legal acts on human rights establish the minimum standards that states must adhere to. Such indicators are considered to be international standards, which include international norms (those human rights recognized by the international community) and principles (in particular, the principles of the rule of law, equality, justice), which establish the rules of conduct of international law entities (Savchuk, 2003, p. 615). It should be noted that such standards both establish the conduct of international law entities and enshrine human rights and freedoms, which must be respected by Member States.

International human rights standards are enshrined in international acts and documents, textually unified and functionally universal (for certain international associations of states) principles and norms, which, through very abstract, mostly evaluative terms and concepts fix the minimum necessary or desired content and/or the scope of human rights, due to the achieved level of social development and its dynamics, as well as establish positive obligations of states to ensure, protect and defend them and provide sanctions of political and legal or political nature for their violations (Rabinovych \& Venetska, 2012). These are universally recognized international legal norms that enshrine the status of an individual at the universal level and establish a list of fundamental rights and freedoms, the obligation of states to respect these rights and freedoms, as well as the limits of possible or permissible their restrictions (Slinko, 2018). That is, international human rights standards are the principles and norms enshrined in international regulatory legal acts that define fundamental human rights and freedoms, the obligation of the state to respect them, assist in their realization, protection and defense against unlawful encroachments and establish liability for their violation and methods of protection.

Modern international law has five types of documents that enshrine fundamental human rights and freedoms, namely (Zaichuk, et al., 2006, p. 216):

(i) The International Bill of Human Rights, which contains the list of inalienable rights.

(ii) Treaties aimed at the prevention and punishment of crimes leading to mass violations of human rights (Convention on the Non-Applicability of Statutory Limitations to War Crimes Against Humanity of 26 October 1968).

(iii) Conventions aimed at protecting groups in need of special care from the state (Convention on the Rights of the Child 1989).

(iv) Conventions aimed at protecting the individual from abuse by state authorities and officials (Geneva Conventions of 1949 on the Protection of War Victims). 
(v) Interstate conferences on human rights, which adopt final documents that are binding for the Member States (the final document of the World Conference on Human Rights-Vienna, 1993).

The main international regulatory legal acts that establish standards of human rights and freedoms, and which should be the basis for the provisions of the Constitution and other regulatory legal acts of Ukraine include: the Universal Declaration of Human Rights (1948), the European Convention for the Protection of Human Rights and Fundamental Freedoms with Protocols (1950), International Covenant on Economic, Social and Cultural Rights (1966), the European Social Model (1961), International Covenant on Civil and Political Rights (1966), Final Act of the Conference on Security and Co-operation in Europe (1975), the Document of the Copenhagen Meeting - the Conference on the Human Dimension of the CSCE (1990).

The Universal Declaration of Human Rights (10 December 1948) defines the following human rights standards: the right to liberty and equality in one's dignity and rights, the right to life, liberty and security of person, the right to recognition of human rights, the right to protection from wrongful acts, the right to restoration of violated rights, the right to be presumed innocent until proven guilty in accordance with the law, the right to secrecy of private and family life, inviolability of home, secrecy of correspondence, the right to freedom of movement and choice of residence, the right to leave the country of residence and return to it, the right to marry and have a family, the right to own property, the right to freedom of thought, conscience and religion, the right to freedom of opinion, peaceful assembly, the right to participate in government directly or through elected representatives, the right to social security, the right to work and its payment, the right to rest, the right to education, to participate in the cultural life of society, the right to social and international order. All these standards are enshrined in the relevant articles of the Constitution of Ukraine (1996).

The Convention for the Protection of Human Rights and Fundamental Freedoms (1950) enshrined the following human rights standards: the right to life, the prohibition of torture, the prohibition of slavery and forced labor, the right to liberty and security of person, the right to a fair trial, no punishment without law, the right to respect private and family life, freedom of thought, conscience and religion, freedom of expression, freedom of assembly and association, the right to marry, the right to an effective remedy, the prohibition of discrimination, the waiver of obligations during an emergency, the restriction of political activity of foreigners, prohibition to abuse the rights.

All these standards are enshrined in the relevant articles of the Constitution of Ukraine (1996), which define the following human rights 
standards: the right to liberty and equality in their dignity and rights (Art. 21), preventing the narrowing of the content and scope of existing rights and freedoms (Art. 22), the right to free development of one's personality (Art. 23), the right to life (Art. 27), the right to respect one's dignity (Art. 28), the right to liberty and security of person (Art. 29), to inviolability housing (Art. 30 ), the right to secrecy of correspondence, telephone conversations, telegraph and other correspondence (Art. 31), prevention of interference with private and family life (Art. 32), freedom of movement, free choice of residence, the right to leave the territory of Ukraine with the exception of restrictions established by law (Art. 33), the right to freedom of thought and speech, the free expression of own views and beliefs (Art. 34), the right to freedom of thought and religion (Art. 35), the right to freedom of association in political parties and public organizations (Art. 36), the right to participate in the management of state affairs, in all-Ukrainian and local referendums, to freely elect and be elected to state authorities and local self-government agencies (Art. 38), the right to assemble peacefully, without weapons and to hold meetings, rallies, marches and demonstrations (Art. 39), the right to send individual or collective written appeals or to personally address state authorities, local self-government agencies and officials and civil servants of these agencies (Art. 40), the right to own, use and dispose of own property, the results of own intellectual, creative activity (Art. 41), the right to entrepreneurial activity, which is not prohibited by law (Art. 42), the right to work, which includes the opportunity to earn a living by work, which is freely chosen or freely agreed to (Art. 43), the right to strike to protect own economic and social interests (Art. 44), the right to rest (Art. 45), the right to social protection (Art. 46), the right to housing (Art. 47), to a sufficient standard of living for oneself and the family (Art. 48), the right to health care, medical assistance and medical insurance (Art. 49), the right to a safe environment for life and health and to compensation for damage caused by violation of this right (Art. 50), the right to marriage and family (Art. 51), the right to education (Art. 53), freedom of literary, artistic, scientific and technical creativity, protection of intellectual property, their copyright, moral and financial interests (Art. 54), the right to court appeal for the decisions, actions or omission of state authorities, local self-government agencies, officials and civil servants, the right to protect own rights and freedoms from violations and unlawful encroachments by any means not prohibited by law (Art. 55), the right to know own rights and responsibilities (Art. 57), the right to professional juridical assistance (Art. 59).

In addition, the article 3 of the Constitution of Ukraine enshrined that the establishment and protection of human rights and freedoms is the main duty of the state. To this end, a number of law enforcement and law- 
enforcement agencies have been established in Ukraine, which in accordance with their tasks should promote the rights, freedoms, legitimate interests of citizens, protect and defend them from illegal actions, promote their restoration in case of violation. The current legislation also provides liability for violations of human rights and freedoms.

Given that Ukraine has signed all international human rights regulations, it is obliged to transpose their provisions into the current legislation. There are currently many forms of interaction between national law and international law in the world. The main one is implementation.

The mechanism for the formation of international and legal standards of human rights in its development has gone through two main stages: (i) collective awareness of the importance of international and legal standards of human rights and (ii) legal consolidation of international and legal standards of human rights (Nalyvaiko \& Stepanenko, 2019). At the same time, constitutional human rights and freedoms cannot be narrower in content than international and legal standards, and all nations should strive for this (Orzikh, 1992, p. 9).

\section{QUESTIONING THE AVAILABLE PROCEDURE IN RECOGNIZING THE NEED OF PROTECTING HUMAN RIGHTS STANDARDS}

Regarding the procedure of implementing international standards of human rights protection into national legislation, it takes place in several stages:

(i) Recognition of human rights by the state and their enshrinement in national legislation. This stage is to recognize international human rights standards by the competent state authority that comply with the current legislation and require implementation in our country, the introduction of the specified standards for the consideration by the Verkhovna Rada of Ukraine, establishing their compliance with the Constitution and laws by the Constitutional Court, further ratification and official publication. This stage also includes a typification of the enshrined right, i.e., its attribution to one of the groups of human rights and freedoms (personal, political, economic, educational, cultural, etc.). Besides, one should establish whether the state has the conditions and means for its implementation, or their implementation requires the involvement of additional financial, logistical or other resources. In the first case, the law may enshrine guarantees of its implementation and protection in addition to the law itself. If such conditions do not exist in the state, the guarantees of implementation will be normatively established only after the creation of appropriate conditions and 
a mechanism for the implementation of the right and its protection. In case when "general social" means are still absent and should be gradually accumulated only in the future, the relevant human right can be "named", declared by the state only as an intention, goal, desire, which should direct its activities to stimulate the gradual formation of appropriate conditions. Any attempts to guarantee the "right" that is not socially (financially) secured by legal means, will be in vain, will look like a kind of state and legal hypocrisy, which can produce legal illusions, legal skepticism and nihilism, discredit constitutional and other legislation - that human rights should be "gradually" ensured by the state, within the "maximum limits of available resources", referred to in the article 2.1 of the International Covenant on Economic, Social and Cultural Rights (Rymarenko, 2006).

(ii) Institutionalization of the standard of human rights protection. This stage consists either in the creation of a special entity that should provide conditions for the realization and protection of relevant human rights, or the imposition of responsibilities for the protection of these rights on the existing competent state authorities.

(iii) Bringing the current legislation in line with the international human rights standard and interpreting the latter. At this stage, it is necessary to analyze the current legislation for the compliance with the approved human rights standard. The establishment of any contradictions requires the earliest possible amendments to regulatory legal acts in order to systematize and adapt them. The need for interpretation of the standard is objectively determined by the dependence of the understanding of universal "standards" (documents that enshrine basic human rights) at least on: the level of development of humanity in the whole and its individual cells, parts; specific historical conditions, which contributed to the formation and operation of the subjects of interpretation and realization of human rights; specific group interests of that part of a socially heterogeneous society (another one does not exist today), the representative and exponent of which is objectively (consciously or unconsciously) the interpreter of the relevant international "standard" or the law of the state (Rymarenko, 2006). It is the correct interpretation that should allow us to clearly understand the content of the standard and correctly implement it in everyday activities. The correct definition of limits for the realization of the corresponding rights and freedoms, as well as the establishment of possible limits of their restriction, if it is necessary, depends on the given activity.

(iv) Establishment of measures and means of protection and defense of human rights. Such measures are implemented by the competent entities in order to prevent, stop possible violations of human rights and freedoms, their restoration in case of violation. Remedies are used in cases and within 
the limits specified by law in order to protect and defend human rights. An example of such measures and means is the preliminary state registration in the Ministry of Justice of Ukraine of all departmental regulations concerning the rights of citizens, obtaining permits to conduct certain activities, etc.

(v) Determining the procedure for the realization of the enshrined right. This stage is the need to establish a sequence of actions for the realization of the relevant right, including its protection from unlawful encroachments or restrictions and restoration in case of violation. Without such a procedure, some rights may remain unrealized. At the same time, there are rights that do not require procedure. In particular, it is applied to a number of personal rights that can be exercised only by human actions (the right to freedom of thought and religion, freedom of literary, artistic, scientific and technical creativity and others).

(vi) Control over the observance of the international standard of human rights. This stage consists in defining the range of entities and their powers that act to verify the state of observance of human rights and freedoms.

Provision of international and legal standards of human rights is realized through: (a) control activities of international agencies in the field of human rights and (b) implementation of international and legal standards of human rights into the national law of United Nations Member States. The institutional control mechanism for the implementation of international human rights standards has a universal and regional dimension. Universal institutional mechanisms are agencies and organizations whose jurisdiction extends to the whole world, regardless of state and regional borders (Nalyvaiko \& Stepanenko, 2019).

\section{CONCLUSION}

Summarizing the above, we can conclude that international law has a very significant impact on national legislation, which is manifested in the implementation of international human rights standards to the Constitution and laws of Ukraine. Member States, under the auspices of the United Nations and the Council of Europe, shall implement all human rights provisions and ensure their implementation and protection on their territory. At the same time, such a process is not complete, which is indicated by the possibility of supplementing human rights and freedoms with new standards. In addition, the implementation of such norms requires both their enshrinement in national legislation and the constant development and improvement of the mechanisms for their implementation and protection. 


\section{REFERENCES}

Ablamskyi, S., Romaniuk, V. V., Chycha, R. P., \& Ablamska, V. V. (2020a). Temporary Access to Documents Containing Medical Confidentiality (Criminal Procedural Aspect). Wiadomości Lekarskie, 73 (5), 1032-1036. Doi: 10.36740/WLek202005136

Ablamskyi, S., Hlobenko, H., Chycha, R. P., Martovytska, O., \& Burlaka, I. (2020b). Ensuring Protection of the Rights of the Aggrieved Person in Criminal Proceedings through the Prism of Requirements of International Law Acts. Journal of Legal, Ethical and Regulatory Issues, 23 (1), 1-7.

Busel, V. T. (2009). Large Explanatory Dictionary of the Modern Ukrainian Language. VTF Perun.

Garzón Buenaventura, E. F. (2016). Innominate Rights in the Inter-American System. DIXI, 18 (24). Doi: https://doi.org/10.16925/di.v18i24.1520

Kyivets, O. V. (2012). European Legal Standards as International and Legal Category. European Studies and Law, 1 (5).

Nalyvaiko, L. R., \& Stepanenko, K. V. (2019). International and Legal Human Rights Standards: Manual. DSUIA.

Orzikh, M. (1992). International and Legal Standards and Human Rights in Ukraine. Law of Ukraine, 4, 7-9.

Rabinovych, P. (2010). Fundamental Human Rights: Socio-Anthropic Nature, Semantic Classification. Law of Ukraine, 2, 18-23.

Rabinovych, P. (2013). Fundamental Human Rights: Socio-Anthropic Essence, Substantial Classification. Journal of the National Academy of Legal Sciences of Ukraine, 2 (73), 10-16.

Rabinovych, P., \& Venetska, O. (2012). International Standards of Human Rights: General Characteristics, Classification. Law Herald of Ukraine, 49, 5-6.

Rymarenko, Y. I. (2006). Private Life and Police Force. Publishing House KNT.

Savchuk, K. O. (2003). International Standards. In Y. S. Shemshuchenko (Ed.), Law Encyclopedia [VI]. Ukr. Encycl.

Shmelova, H. H. (2014). International and Legal Guarantees of Human Rights: General Theoretical Aspect. Legal Novels: Scientific and Professional Journal, 1, 99103.

Silantieva, E. E. (2021). Correlation of Formal Clarity and Rule of Law. Law and Safety, 80 (1), 28-34. Doi: https://doi.org/10.32631/pb.2021.1.03

Slinko, T. M. (15-V-2018). International and Legal Standards in the Field of Human Rights and Their Reflection in the Constitution of Ukraine. Human Rights and Democracy: Collection of Scientific Papers Regarding the Materials of Scientific Conference, 30-34. Kharkiv, Ukraine. 
Tkalych, M., Safonchyk, O., \& Tolmachevska, Y. (2020). Private Law and Human Rights: New Realities. DIXI, 22 (2), 1-12. Doi: https://doi.org/10.16925/23575891.2020.02.04

Ukraine (1996). Constitution of Ukraine [28 June 1996]. Law of Ukraine No. 254k/96VR. Bulletin of the Verkhovna Rada of Ukraine, 30.

United Nations (1948). Universal Declaration of Human Rights, 10 December 1948.

United Nations (1950). Convention for the Protection of Human Rights and Fundamental Freedoms, 4 November 1950.

Viktor, F., HerasymchukS., Zuieva, O., Tuieva, O., \& Kartsyhin, D. (2021). Protection of Property Rights of Citizens in the Conditions of Foreign Military Aggression: Political and Legal Experience of Ukraine. Political Questions, 39 (69), 198211. Doi: https://doi.org/10.46398/cuestpol.3969.11

Zaichuk, O. (2006). Theory of State and Law. In O. Zaichuk \& N. M. Onishchenko (Eds.), Academic Course: Textbook for Law Students of Higher Educational Institutions. Yurinkom Inter.

Zozulia, O. I. (2020). Economic, Social and Cultural Human Rights in the Context of Preventing the Spread of Covid-19 in Ukraine. Law and Safety, 77 (2), 156163. Doi: https://doi.org/10.32631/pb.2020.2.21 